\title{
A comparative evaluation of methods for estimating the colostrum quality in sows
}

[Avaliação comparativa de métodos para estimar a qualidade do colostro em porcas]

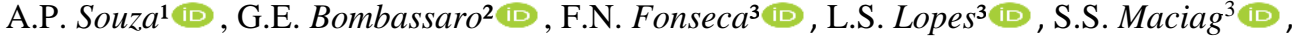 \\ F.B. Volpato $^{2}$, A.P. Bastos ${ }^{4 *}$ (D) \\ ${ }^{1}$ Faculdade Concórdia, Concórdia, SC, Brasil \\ ${ }^{2}$ Instituto Federal Catarinense, Concórdia, SC, Brasil \\ ${ }^{3}$ Universidade Estadual do Centro-Oeste do Paraná, Guarapuava, PR, Brasil \\ ${ }^{4}$ Embrapa Suínos e Aves, Concórdia, SC, Brasil
}

\begin{abstract}
Colostrum is the main source of immunoglobulins ( $\mathrm{Ig}$ ) for neonate piglets and plays a crucial role within the health and growth of the piglet. Currently in pig farming, there are still no widespread practical methods for measuring the Ig concentration in colostrum at herd level. We evaluated sows' colostrum IgG concentration using an optical and a digital Brix refractometer and their performance was correlated to an IgG ELISA test, and flow cytometry. Colostrum concentrations of IgG and IgA averaged $74.05 \pm$ $21.37 \mathrm{mg} / \mathrm{mL}$ and $20.2 \pm 5.32 \mathrm{mg} / \mathrm{mL}$ respectively. The mean value of the Brix percentages for optical refractometer was $26.32 \%$, and for digital was $28.32 \%$. The Brix refractometer measurements of colostrum samples presented high correlation for IgG content analyzed by ELISA (Optical $=0.74$, Digital $=0.87 ; \mathrm{P}$ $<0.001)$. Considering the immunophenotyping, the values for IgG and IgA lymphoblasts indicated a highly significant relationship to ELISA ( $\operatorname{IgG}=0.77, \operatorname{IgA}=0.84 ; \mathrm{P}<0.001$ ). The Brix refractometer can be considered a useful tool to be included in a colostrum monitoring program to improve potentially neonatal health. In addition, we demonstrated that flow cytometry can be an important tool to analyze and characterize the immunological potential of sow colostrum.
\end{abstract}

Keywords: colostrum quality, immunoglobulin G, swine, Brix refractometer, flow cytometry

\section{RESUMO}

O colostro é a principal fonte de imunoglobulinas (Ig) para leitões recém-nascidos e desempenha um papel crucial na saúde e no crescimento dos leitões. Atualmente, na suinocultura, ainda não existem métodos amplamente utilizados na prática de produção para medir a concentração de imunoglobulinas no colostro suíno. Avaliou-se a concentração de $\operatorname{Ig} G$ no colostro de porcas usando refratômetros Brix óptico e digital, e o desempenho foi comparado com ELISA e citometria de fluxo. As concentrações de IgG e IgA no colostro foram $74,05 \pm 21,37 \mathrm{mg} / \mathrm{mL}$ e 20,2 $\pm 5,32 \mathrm{mg} / \mathrm{mL}$, respectivamente. A percentagem de Brix média das amostras de colostro para o refratômetro óptico foi $26,32 \%$, e para o digital foi $28,32 \%$. As medições dos refratômetros de Brix apresentaram elevada correlação com a concentrações de IgG medidas por ELISA (óptico=0,74, digital=0,87; $P<0,001)$. Considerando a imunofenotipagem, os valores dos linfoblastos Ig $G$ e IgA apresentaram alta correlação com o ELISA (IgG=0,77, IgA=0,84; $P<0,001)$. O refratômetro Brix pode ser considerado uma ferramenta útil para ser incluída em um programa de monitoramento de colostro para melhorar a saúde neonatal. Além disso, foi demonstrado que a citometria de fluxo pode ser uma ferramenta importante para analisar e caracterizar o potencial imunológico do colostro de porcas.

Palavras-chave: qualidade do colostro, imunoglobulina $G$, suíno, refratômetro de Brix, citometria de fluxo

\section{INTRODUCTION}

Pigs are born with low energy reserves (Mellor and Cockburn, 1986) and without immune protection (Edwards, 2002). Insufficient colostrum intake has been identified as an important reason for neonatal death in pig production (Edwards, 2002), being the highest

*Corresponding author: ana.bastos@embrapa.br

Submitted: December 23, 2020. Accepted: March 12, 2021. 
mortality rate of piglets in the first 3 days of birth during the pre-weaning period (Tuchscherer et al., 2000). The key causes for piglet mortality in early life are low birth weight, inappropriate colostrum intake, hypoglycemia, and hypothermia (Le Dividich et al., 2005). The roles of colostrum are, therefore, to favor the production of energy for the thermoregulation of the piglet (Le Dividich et al., 2005 ), to promote the passive immunity to prevent infections (Rooke and Bland, 2002; Le Dividich et al., 2005), and it plays a crucial role within the intestinal development of the piglet (Xu et al., 2000).

Immunoglobulin $\mathrm{G}$ ( $\mathrm{IgG}$ ) is the most clinically important globulin during the first weeks of life, and the concentration of $\operatorname{IgG}$ within the plasma of piglets shortly after birth is positively correlated with their survival. Additionally, in terms of $\operatorname{IgG}$ content, dead piglets have lower serum concentration than their surviving fellow piglets, indicating low colostrum intake (Vallet et al., 2013; Ferrari et al., 2014). It is, therefore, more likely that the reduced growth and more mortality in gilt progeny compared to sow progeny could also be a consequence of an immunologically poor colostrum and milk production (CarneyHinkle et al., 2013). Besides, the colostrum IgG contents vary greatly among sows (Foisnet et al., 2010). Normally, the IgG concentration in porcine colostrum is reported to range from 48.0 to 95.6mg/mL (Tuchscherer et al., 2000; Quesnel, 2011).

Factors affecting the entire colostrum yield are related to aspects of the environment, more precisely, sow and piglet characteristics (Devillers et al.; 2007; Quesnel, 2011). So, genotype, parity, age, vaccination status, and endocrine status of the sow, as well as nutritional and herd handling, are reported to influence colostrum yield and composition (Devillers et al., 2007; Foisnet et al., 2010; Vallet et al., 2013). Concentration of $\mathrm{IgG}$ in maternal colostrum significantly affects the acquired immunity, and thus, knowing the $\mathrm{IgG}$ content of colostrum through accurate measurement is crucial for proper management and to scale back piglet preweaning mortality as well Some methods are available to evaluate colostrum quality in several species, but in pigs this assessment is still scarce. And so far, there are few studies on a method for this purpose.
The main methodologies for evaluating the quality of colostrum are RID and ELISA (Hasan et al., 2016). Regarding accuracy, the best method for analysis of IgG in the colostrum is RID assay, which represents the gold standard, and ELISA, that directly measures the $\operatorname{IgG}$ concentration. However, RID assay is an expensive procedure, and it demands special equipment and skilled technicians. Also, it is time consuming so that it cannot be used routinely on farms because it requires from 18 to $72 \mathrm{~h}$ to determine the results (Fleenor and Stott, 1981). The ELISA test can provide advantages over immunodiffusion in terms of cost, time and ability to measure a large number of samples at one time, being the most commonly analytical method to measure swine colostrum IgG concentration.

To simplify colostrum evaluation, physical techniques, like refractometry, are used for colostrum quality control. For that, both digital and optical refractometers are used to measure total protein in colostrum. Considering that the major protein fraction in the colostrum is $\mathrm{IgG}$, this parameter may be correlated with IgG concentration (Quigley et al., 2013). In this sense, measurement of relative density has been employed to estimate colostrum IgG concentration (Fleenor and Stott, 1981); in addition, the quantification of $\operatorname{IgG}$ using the Brix refractometer seems to be the most promising method to on-farm monitoring of colostrum quality, because it requires minimal amounts of sample, and it is fast, easy to perform and not expensive in terms of equipment and reagents.

Quantification of $\operatorname{IgG}$ can also be performed using flow cytometry. This method allows the identification and quantification of cells in suspension, through fast and automatic processing of a large number of cells. In this technique, cells are labeled with specific monoclonal antibodies, allowing the qualitative and quantitative analysis based on cell size, internal granularity and fluorescence intensity. This approach makes flow cytometry a powerful tool for detailed analysis of complex populations in a short period of time. Although flow cytometry is a well-established technique, there are few studies using it to investigate the cell composition of sow colostrum. Thus, it is extremely important to validate flow cytometry as an efficient alternative for the assessment of porcine colostrum. 
Based on these aspects, the search for validated and reliable methods to fast quality control and to identify the different cell subpopulations in colostrum is required to improve piglet handling and to facilitate the investigation of the potential role of immune cells in passive immunity. So, this research aimed to evaluate the concordance between the refractometry values obtained by optical and digital Brix and their correlation to the IgG concentration determined with ELISA and flow cytometry. Besides, the study also compared flow cytometry analysis to estimate $\operatorname{IgG}$ and $\operatorname{IgA}$ content of sow, matching it to ELISA assays.

\section{MATERIALS AND METHODS}

This study was approved by the Ethical committee of the Embrapa Suínos e Aves (CEUA: 001/2016). The experiment was carried out at a farm with 1100 PIC sows in an exceedingly 2week batch system. The experiment was conducted on 20 crossbred Landrace (LR) 3 Large White (LR3LW) sows of mixed parities (from 1 to 6). Sows were artificially inseminated within 3 to 5 days after weaning. During gestation, the sows were housed individually on a slatted floor. Sows had free access to water and were fed twice a day on a conventional gestation diet. The gestation diet was provided until the second day of lactation. Sows were shifted to a farrowing house $\sim 1$ week before the expected date of farrowing and kept in individual farrowing crates $(200 \mathrm{~cm} \times 80 \mathrm{~cm})$ equipped with a feeder and drinker. Ambient temperature averaged $21^{\circ} \mathrm{C}$. Parturition was observed with minimal interference in the farrowing process. The birth of the first piglet was considered to represent the start of parturition.

Colostrum samples $(n=127)$ were obtained immediately after birth of the first piglet. The samples $(20 \mathrm{~mL})$ were manually milked from the pairs of teats located within the anterior, middle, and posterior parts of the udder, without the utilization of oxytocin. Samples were placed into plastic vials labeled with sow identification number and collection date. One part of the colostrum sample was analyzed immediately, and the remaining fraction was frozen at $-80^{\circ} \mathrm{C}$ until further analysis.

Brix measurements were performed using an optical Brix refractometer (Model 300001; Sper Scientific, Scottsdale, AZ), with a scale from 0 to
$32 \%$ Brix, and a digital Brix refractometer (PAL1, Atago Co. Ltd., Bellevue, WA), with a scale from 0 to $52 \%$ Brix. These devices are commonly used to measure the $\%$ sucrose in liquids, but also to estimate the total solids content (TS \%) for nonsucrose-containing (Quigley et al., 2013). To use the optical Brix refractometer, an individual must peer into the instrument and determine the percentage Brix of the liquid being analyzed by identifying a blue line on the scale. On the contrary, the digital Brix device determines the Brix score of the liquid based on the refractive index of a light source applied to the sample (Bielmann et al., 2010).

In the present study, the Brix percentages were determined with optical and digital brix refractometers shortly after collection. The colostrum sample was well-mixed and an aliquot $(0.3 \mathrm{~mL})$ was placed on both refractometers' prism and the Brix percentages (\%) were recorded (in duplicate for each device). To avoid interferences, all procedures were performed by the same individual. Prior to each evaluation, the refractometers were cleaned and calibrated with distilled water, and the Brix percentages (\%) were recorded (in duplicate for each device). We defined a cut-off point of $50 \mathrm{mg} / \mathrm{mL}$ as an adequate level of IgG at early colostrogenesis according to the findings of different studies that demonstrated an average level of $64 \mathrm{mg} / \mathrm{mL}$, ranging from 52 to $102 \mathrm{mg} / \mathrm{mL}$, shortly after farrowing (MarkowskaDaniel et al., 2010; Hurley and Theil, 2011; Hasan et al., 2016).

The concentrations of IgG and IgA in colostrum were determined by ELISA. Colostrum samples were thawed and then warmed to ensure homogeneity of fat and other particles. The colostrum samples were centrifuged $(1,300 \mathrm{xg}$ at 4 ${ }^{\circ} \mathrm{C}$ for $20 \mathrm{~min}$ ) to fat removal. All colostrum samples were diluted 1:500,000 (v/v) with proper diluent (50 mM Tris buffer, $0.14 \mathrm{M} \mathrm{NaCl}, 1 \%$ BSA, and $0.05 \%$ Tween 20). The ELISA procedure used for colostrum was adapted from instructions provided by the manufacturer (Bethyl Laboratories, Montgomery, TX) and the protocol described by Devillers et al. (2004). All samples were analyzed in duplicate. The plates were read on a microplate reader (Thermolab System, MRX Revelation, Chantilly, VA) at $540 \mathrm{~nm}$. The results were obtained in $\mathrm{ng} / \mathrm{mL}$ but expressed inmg/mL after appropriate dilution correction. 
Colostrum samples were diluted 1:4 (v/v) in PBS containing $5 \%$ fetal calf serum (FCS) and centrifuged for $10 \mathrm{~min}$ at $400 \mathrm{x} \mathrm{g}$. The fat upper layer was discarded. The viability of the cells, evaluated by the trypan blue exclusion test, was nearly 90 per cent. Fifty microliters of colostrum cells suspensions were diluted in flow cytometry buffer at approximately $1 \times 10^{6}$ cells $/ \mathrm{mL}$ and incubated for $30 \mathrm{~min}$ at room temperature with a cocktail of specific monoclonal antibodies (mAb): isotypes controls; mouse anti-pig CD79a (MB-1 clone, PE conjugated); mouse anti-bovine WC4 (synonym SWC7 or CD19, clone CC55, APC conjugated), mouse anti-pig IgG (K61 1B4 clone, FITC conjugated); and mouse anti-pig IgA (K61 1B4 clone, FITC conjugated). The cells were first resuspended in Cytofix/Cytoperm solution (BD Biosciences); then, washed twice with BD Perm/Wash (BD Biosciences) to keep cells permeabilized to favor staining of the intracellular molecule CD79a. After, the following fluorochrome-labeled mAbs were used: panel A): FITC-IgG, PE-CD79a, 7-AAD (BD Biosciences), APC-SWC7; and panel B): FITC-IgA, PECD79a, 7-AAD, APC-SWC7.

After staining, colostrum cells were washed, resuspended in $150 \mu \mathrm{L}$ of $\mathrm{BD}$ stabilizing fixative and transferred to a plate. Before sample analysis, the flow cytometer settings were checked using Cytometer Setup and Tracking beads (CS\&T beads, BD) as described at the manufacturer's instructions. Compensation beads were used with single stains of every antibody to establish the compensation settings. The compensation matrix was identically applied to all samples. Side scatter (SSC) threshold level was set at 8,000 units to eliminate debris. Gates were carried out systematically on each sample, allowing minor adjustments for SSC variability. For determination of the phenotype of CD79a positive cells, the forward/side scatter characteristics were used for estimation of the lymphocyte population and exclusion of debris, followed by gating the CD79a positive cells; and then, $\operatorname{IgG}$ or $\operatorname{IgA}$ lymphoblasts were subsequently gated. Flow cytometry was performed with Accuri ${ }^{\circledR}$ flow cytometer (Becton Dickinson).

Descriptive statistics were carried out to present optical Brix refractometer scores for colostrum samples, digital Brix refractometer, ELISA for IgG and IgA immunoglobulin, and flow cytometry for lymphoblasts. In addition, optical and digital Brix refractometer scores were plotted against Elisa test for colostrum samples. Correlation analysis (Pearson coefficient) was performed to evaluate the association among the refractometry analyses (optical and digital) and ELISA assay using PROC CORR do SAS ${ }^{\text {TM }}$ (2012). Complementarily, concordance analysis was carried out to compare the optical and digital refractometry using software R.

\section{RESULTS}

A total of 127 colostrum samples were collected from multiparous sows $(n=85)$ and gilts $(n=42)$. The sows were of various litter sizes (from 10 to 13 piglets) and various lactation numbers (from 3 to 7). As such, 127 colostrum samples were assessed for Ig concentrations by ELISA. The mean of the $\mathrm{IgG}$ concentrations was $74.05 \mathrm{mg} / \mathrm{mL}$. The IgG concentrations showed a normal distribution and ranged from 45.76 to $123.4 \mathrm{mg} / \mathrm{mL}$ (Figure 1). Only 10 samples $(7.87 \%$ ) were below the standard cut-off point of $50 \mathrm{mg} / \mathrm{mL}$ for $\mathrm{IgG}$ concentration. Mean concentration of IgA after farrowing was $20.2 \mathrm{mg} / \mathrm{mL}$, and its range was 10.95 to 31.97 (Table 1)

Digital and optical brix refractometer scores for colostrum samples are shown in Figure 2. The Brix scores ranged from 15.3 to $38.8 \%$ and 12.0 to $30.0 \%$ for the digital and optical Brix refractometers, respectively. The samples measured using the digital Brix instrument had a mean and median Brix value of 28.32 and $35.0 \%$, respectively. For optical Brix instrument mean and median were 26.38 and $27.0 \%$, respectively. Regarding the digital brix refractometer data, 112 samples $(83.58 \%$ ) were above $25 \%$ Brix, which is the cut-point recommended by Hasan et al. (2016). For the optical Brix refractometer, 108 out of 127 samples measured $>25 \%$ Brix, suggesting the data were not normally distributed. In addition, for the optical Brix refractometer, 5 of the samples measured above $30.0 \%$ (device upper limit), truncating the upper level of the distribution (Figure 2). 


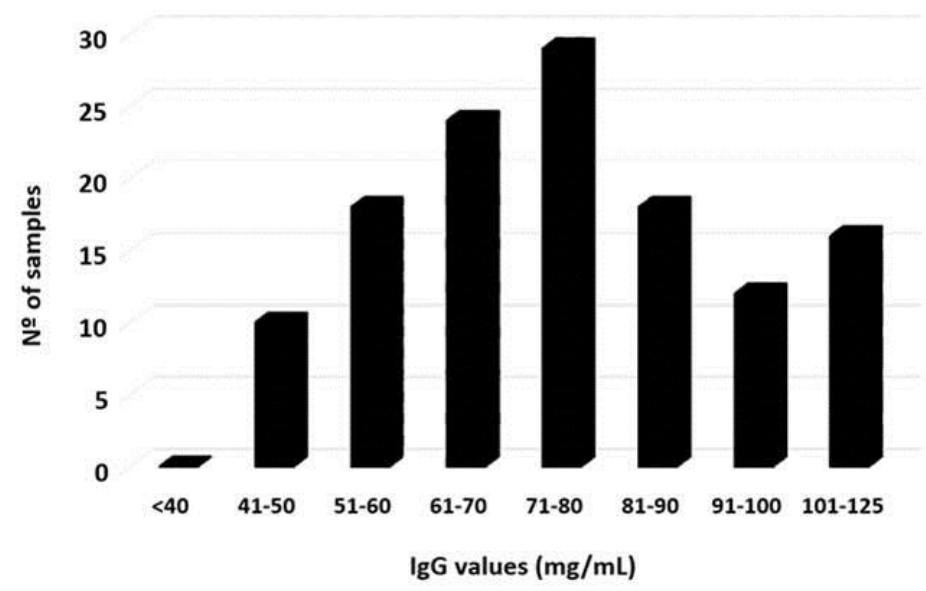

Figure 1. A distribution plot of IgG concentrations of 127 colostrum samples from sows.

Table 1. Descriptive statistics of colostrum data obtained by different techniques

\begin{tabular}{lcccc}
\multicolumn{1}{c}{ Item } & Mean & SD & Minimum & Maximum \\
\hline IgG by ELISA (mg/mL) & 74.05 & 21.37 & 45.76 & 123.40 \\
IgG lymphoblast- Flow cytometer (\%) & 6.44 & 1.44 & 3.60 & 9.70 \\
Digital Brix (\%) & 28.32 & 0.05 & 15.3 & 38.8 \\
Optical Brix (\%) & 26.38 & 0.04 & 12 & 30 \\
IgA by ELISA (mg/mL) & 20.20 & 5.32 & 10.95 & 31.97 \\
IgA lymphoblast- Flow cytometer $(\%)$ & 3.68 & 0.83 & 2.10 & 6.90 \\
\hline
\end{tabular}

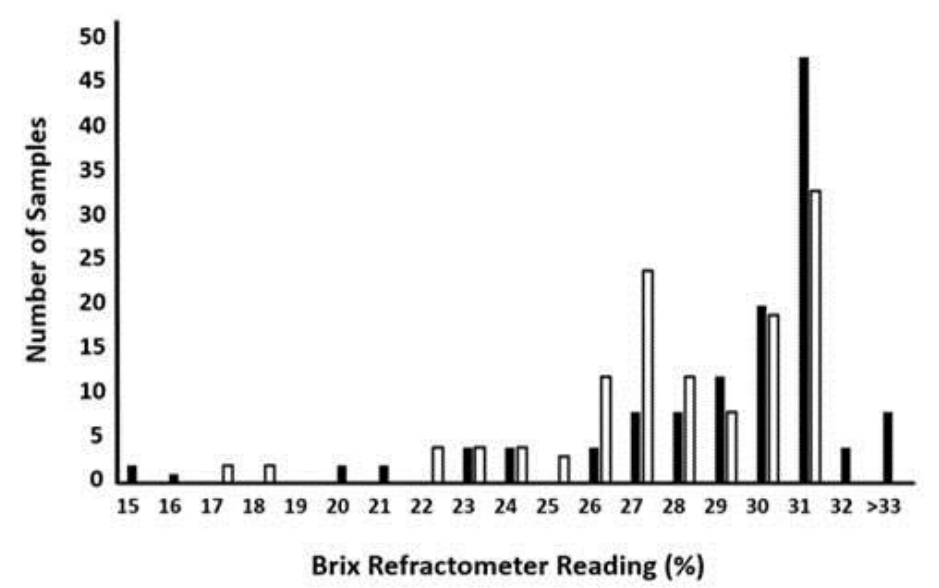

Digital Brix Refractometer

Doptical Brix Refractometer

Brix Refractometer Reading (\%)

Figure 2. Distribution of colostrum samples analyzed with a digital and optical Brix refractometer $(\mathrm{n}=$ 127). The optical refractometer had a limit of $30 \%$ on the scale, resulting in a truncated tail in the distribution.

Microscopic viability evaluation and trypan blue exclusion staining were performed before flow cytometric analysis. The evaluated colostrum were rich in cells (about $6 \times 10^{6}$ cells $/ \mathrm{mL}$ ), and their cell viability was greater than $92 \%$. A summary of the B-cellular components in the colostrum is shown in Table 2. The gate to identify B lymphocyte populations was not based on forward scatter (FSC) and side scatter (SSC) properties, but they were used for estimation of the lymphocyte population and exclusion of debris (Figure 3 ). We excluded doublets and dead cells using FSC height and CD79 $\mathrm{a}^{+}$expression. Among B-lymphocytes, $\mathrm{CD} 79 \mathrm{a}^{+} \mathrm{SWC}^{+} \mathrm{IgG}^{+}$ cells $(6.44 \pm 1.435 \%)$ were more numerous than $\mathrm{CD} 79 \mathrm{a}^{+} \mathrm{SWC}{ }^{+} \mathrm{IgA} \mathrm{A}^{+}$cells $(3.65 \pm 0.826 \%)$. 
Correlation between Elisa, both refractometer instruments (optical and digital), and immunophenotyping of lymphoblasts cells by flow cytometer were determined. Pearson coefficients are shown in Table 3 . The correlation between ELISA-measured IgG concentrations and the optical Brix refractometer values was 0.74 ( $\mathrm{P}<0.001$; Figure 4), whereas the digital one had higher correlation coefficient $(0.87, \mathrm{P}<0.001)$. Moreover, the values of percentage of immunophenotyping of lymphoblasts $\operatorname{IgG}$ and ELISA-measured IgG concentrations indicated high significant relationship $(0.77 ; \mathrm{P}<0.001)$. In addition, it was observed a correlation between lymphoblasts $\operatorname{IgA}$ and ELISA-measured $\operatorname{IgA}$ concentrations $(0.84 ; \mathrm{P}<0.001)$. According to the Bland-Altman plot for concordance analysis between digital and optical refractometers (Figure 5), bias was 0.02 (2\%) and significantly different from $0(\mathrm{P}=0.0002)$, indicating that there is no concordance between the devices, despite there is a strong correlation. The plot also shows that the differences among the variables seem to be dependent on the measurement value $(\mathrm{r}=0.3705$, $\mathrm{p}=0.0402$ ).

Table 2. Comparison of immune cellular components in colostrum from sows

\begin{tabular}{lcc}
\hline \multicolumn{1}{c}{ B lymphoblasts (\%) } & Colostrum samples & Phenotype \\
\hline $\mathrm{CD}^{\prime} \mathrm{a}^{+}$ & $18.97 \pm 1.002$ & precursor B-cell type \\
$\mathrm{CD}^{+} \mathrm{a}^{+} \mathrm{SWC7}^{+}$ & $15.97 \pm 1.342$ & B-cell population \\
$\mathrm{CD}^{+} 9 \mathrm{a}^{+} \mathrm{SWC7}^{+} \mathrm{IgG}^{+}$ & $6.44 \pm 1.435$ & IgG lymphoblast \\
$\mathrm{CD}^{+} 9 \mathrm{a}^{+} \mathrm{SWC7}^{+} \mathrm{IgA}^{+}$ & $3.65 \pm 0.826$ & IgA lymphoblast \\
\hline
\end{tabular}
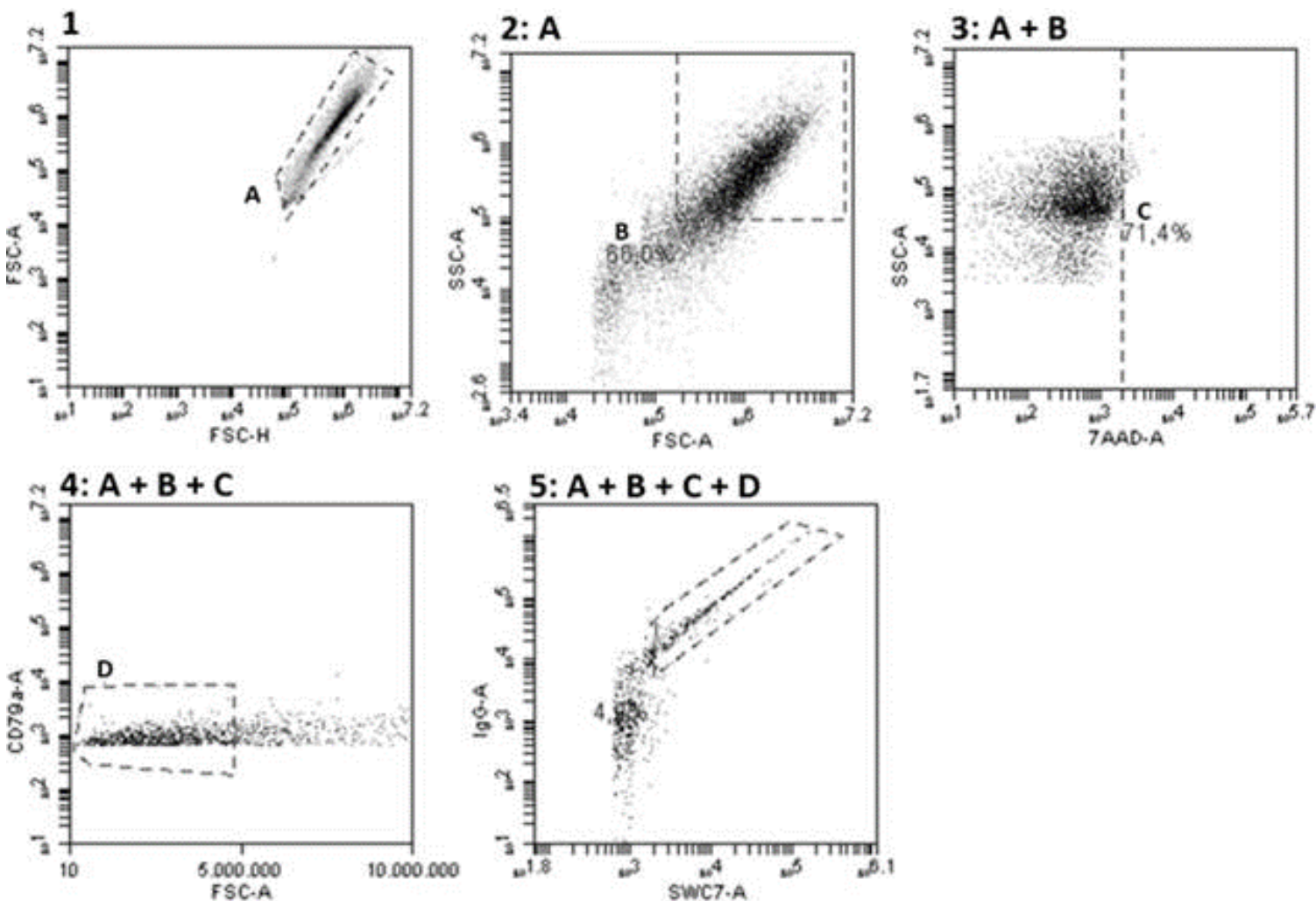

Figure 3. Immunoglobulin expression of $\mathrm{IgG}$, and $\mathrm{IgA}$ on the $\mathrm{CD} 19$ mature B cell population. (A) Representative flow cytometry dot plots highlighting the CD79a and SWC7 double-positive cells and IgG expression. 
Table 3. Person correlation coefficients

\begin{tabular}{lcccc}
\hline \multicolumn{1}{c}{ Variable } & Digital Brix & Optical Brix & ELISA IgG & Flow cytometry \\
\hline Digital Brix & 1.0 & 0.85161 & 0.86824 & 0.73259 \\
& & $\mathrm{P}<0.0001$ & $\mathrm{P}<0.0001$ & $\mathrm{P}<0.0001$ \\
Optical Brix & 0.85161 & 1.0 & 0.74790 & 0.48512 \\
& $\mathrm{P}<0.0001$ & 0.74790 & $\mathrm{P}<0.0001$ & $\mathrm{P}=0.0057$ \\
IgG-ELISA & 0.86824 & $\mathrm{P}<0.0001$ & 1.0 & 0.77072 \\
& 0.73259 & 0.48512 & 0.77072 & $\mathrm{P}<0.0001$ \\
Flow cytometry & $\mathrm{P}<0.0001$ & $\mathrm{P}=0.0057$ & $\mathrm{P}<0.0001$ & 1.0 \\
& & &
\end{tabular}

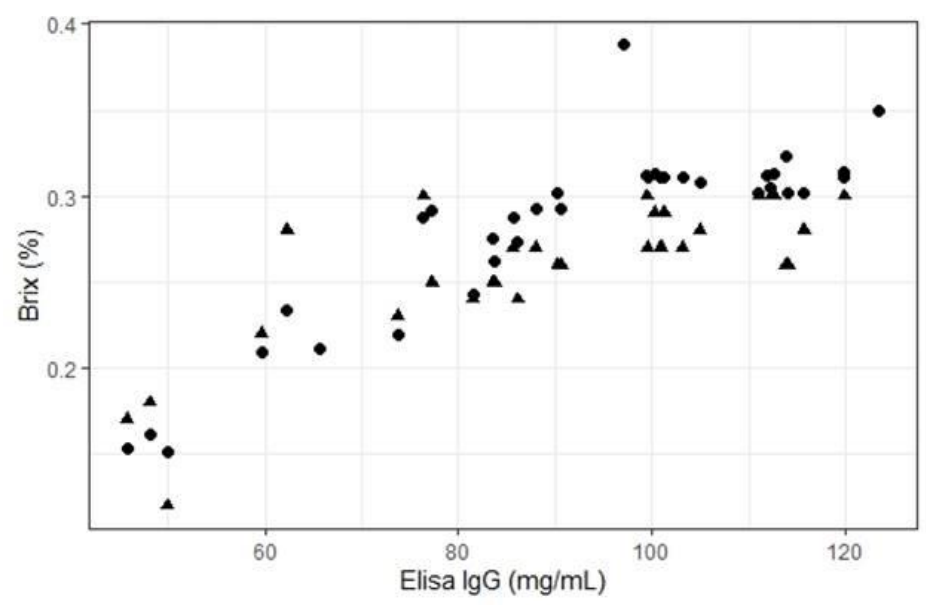

Figure 4. Correlation plot of Brix refractometers for assessment of colostrum quality in relation to ELISA. $(\boldsymbol{\Delta})$ Optical refractometer $(\bullet)$ Digital refractometer.

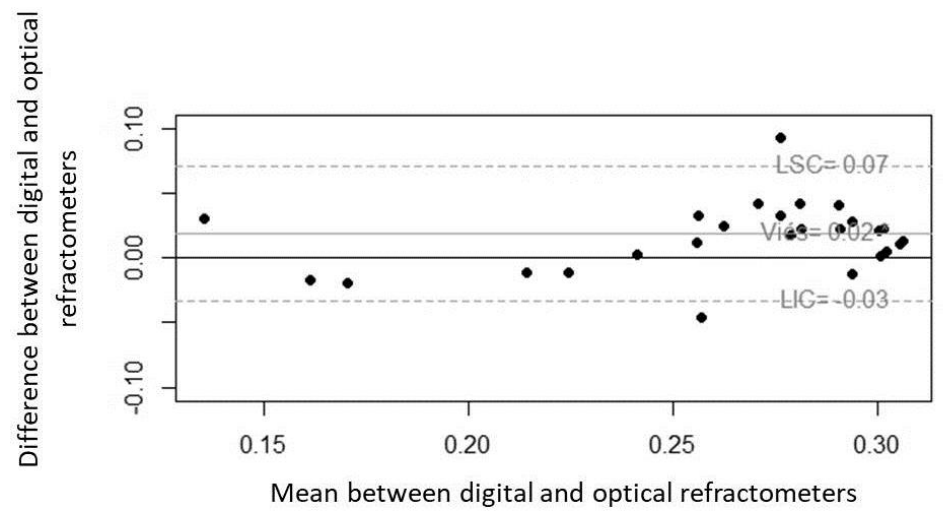

Figure 5. Bland-Altman plot for concordance analysis between digital and optical refractometers.

\section{DISCUSSION}

In this study, the mean of ELISA-measured colostrum IgG concentration was $74.05 \mathrm{mg} / \mathrm{mL}$ $(\mathrm{n}=127)$ ranged from 45.76 to $123.4 \mathrm{mg} / \mathrm{mL}$. These IgG concentrations are consistent with previous results (Quesnel, 2011; Cabrera et al., 2012). In fact, IgG is considered as the most reliable indicator of successful transfer of passive immunity to newborn piglets. The immunity transfer is considered successful if piglets reach a serum IgG level of $26-28 \mathrm{mg} / \mathrm{mL}$ in within 24 hours after birth (Devillers et al., 2011), and if body-weight gain is $50 \mathrm{~g}$, on average (Devillers et al., 2004; Le Dividich et al., 2005). To achieve this passive immunity level, piglets need to be fed at least 250-300 g/day of good quality colostrum in the first 24 hours after birth (Devillers et al., 2007; Quesnel, 2011). 
Concentrations of $\operatorname{IgG}$ in colostrum decrease quickly, so colostrum samples were obtained immediately after birth of the first piglet. Four hours after the onset of parturition, the colostrum may be already reduced until 20\% (Klobasa and Butler, 1987). Based on the assumption that piglets need to receive IgG to ensure they have sufficient immunity against disease not only after birth, but also after weaning, the $\operatorname{IgG}$ concentration in sow colostrum of $50 \mathrm{mg} / \mathrm{mL}$ is considered as a cut-off value between good and bad quality colostrum (Hasan et al., 2016; Balzani et al., 2016). Our results show that only $7.87 \%$ samples $(n=10)$ were below the standard cut-off point. Although ELISA is a method used to directly quantify immunoglobulins in the colostrum, it is expensive and cannot be used routinely on farms, being restricted to be used in specialized laboratories. The practical major point in assessing colostrum IgG content at farm level might be to identify those sows producing colostrum with low level of immunoglobulins (Hasan et al., 2016).

The Brix refractometer has been successfully used as a method of estimating $\mathrm{IgG}$ concentration in the colostrum of sheep (Harker, 1978), horses (Cash, 1999), cattle (Bielmann et al., 2010) and caprine (Zobel et al., 2020). For swine colostrum, few data are available, only two studies evaluated the relationship between digital Brix refractometer with radial immunodiffusion (Balzani et al., 2016) and ELISA (Hasan et al., 2016). The main concern about this technique, in terms of optical Brix refractometer, is that the obtained values may differ depending on the technician's skills, whereas the digital Brix refractometer may provide more consistent results, if used and cleaned properly, due to the absence of subjective data acquisition.

Our results show a correlation between the Brix values and the concentrations of IgG determined by ELISA, which were positive and highly significant $\quad$ (Optical $=0.75, \quad$ Digital $=0.87$; $\mathrm{P}<0.001)$. Hasan et al. (2016) also showed that digital Brix refractometer could be a rapid and accurate tool for the determination of colostrum quality. However, it is important to highlight that our findings on digital Brix refractometer correlation coefficients $(\mathrm{r}=0.87 ; \mathrm{n}=127)$ were higher in comparison to the findings of that study $(\mathrm{r}=0.63 ; \mathrm{n}=153)$. Additionally, we found that there was significant correlation between flow cytometry and Brix values (Optical $=0.48$, Digital $=0.73 ; \quad \mathrm{P}<0.001$ ). Consequently, Brix refractometry shows good potential for reliably estimating IgG concentrations in sow colostrum and can be recommended to aid colostrum management decisions on farms. On the other hand, it is also necessary to verify if there is concordance between the two devices (digital and optical).

The Bland-Altman analysis for concordance between methods is the most proper methodology. It is focused on the Bland-Altman plot, which is a dispersion plot related to the means of both methods in the $\mathrm{X}$ axis, and the bias (difference between the measurements of both methods) in the $\mathrm{Y}$ axis. From this graph, the relation of the discordances and the evaluated measurements are observed, the bias (how much the difference strays from zero), the error (the dispersion of the differences points around the mean) and tendencies, showing the limits of concordance and their confidence intervals. In this work, optical and digital refractometers did not present concordance among the results for the same samples. Thus, despite both digital and optical Brix refractometers showed potential in determining colostrum quality if compared to ELISA, digital refractometers should be the option for on farm analysis as it has the best correlation coefficient.

Acquisition of high-quality colostrum is an important factor influencing neonatal piglet's health, and insufficient concentration of IgG in colostrum results in failure of the transfer of passive immunity (Kielland et al., 2015). Consequently, an estimation of IgG content might be a useful tool for proper on-farm colostrum management. This is a relevant issue, especially when there are large litters, and cross-fostering and split suckling are common management practices employed to maximize colostrum intake. In large litters, each piglet has access to a small portion of colostrum. In this situation, if the evaluated colostrum IgG content is considered poor, farmers can pay more attention to those management practices in advance to guarantee the proper IgG concentration to the piglet for best development (Oliviero, 2013).

Brix refractometer seems to be an acceptable method to assess colostrum $\mathrm{IgG}$ content at herd level during the initial hours of parturition, when 
IgG are expected to peak, and the digital device provides better results in comparison to optical. There are many advantages for this technique such as durable and affordable instrumentation, no expertise required for assay execution, and the calibration process is simple, making it a very rapid and practical farm tool (Balzani et al., 2016). Future studies involving the use of the Brix refractometer should note the use of Brix refractometer in late colostrogenesis (after 4 hours) and the establishment of cut-offs across the scale for categorizing colostrum to guide piglets handling.

An important aspect of colostrum, aside to the $\operatorname{IgG}$ content, is the cellular composition, and for that flow cytometry allows a deeper investigation of cell subsets (lymphocyte) in colostrum samples. Thus, cell characterization of sow colostrum can contribute to a better understanding of the factors that affect its performance and composition. In the present study, we undertook an analysis of the distribution and expression of activation markers in B-Lymphoblasts isolated from porcine colostrum using the flow cytometry. B lymphocytes are an essential component of the adaptive immune system and provide antibodymediated protection against infections. The results showed that B-lymphocytes represented about $16 \%$ of all lymphocytes of mammary secretions, which was consistent with results obtained by Le Jan (1994) and Markowska-Daniel et al. (2010).

Porcine colostrum is characterized by $\mathrm{IgG}$ representing the predominant class of immunoglobulins, but there are also small amounts of $\operatorname{IgM}$ and $\operatorname{IgA}$ and a rich mixture of bioactive molecules like growth factors and enzymes. $\operatorname{IgA}$ appears in secretions for a long period after parturition and has general function in gastrointestinal tract by local safety in piglets. Therefore, our results showed that the $\operatorname{IgA}$ measurement by ELISA correlated with the analyses of flow cytometry. Among Blymphoblasts, $\quad$ CD79a+SWC7+IgG+ cells $(6.44 \pm 1.435 \%)$ were more numerous than CD79a+SWC7+IgA+ cells $(3.65 \pm 0.826 \%)$. The level of IgG may be three-four times higher than the level of $\operatorname{IgA}$ and $\operatorname{IgG}$ in the serum of the sow (Schnulle and Hurley, 2003). We showed a correlation between immunophenotyping of lymphoblasts $\operatorname{IgG}$ and $\operatorname{IgA}$ and measured concentrations by ELISA. Therefore, flow cytometry can be an important tool to analyze and characterize the immunological potential of colostrum.

\section{CONCLUSIONS}

Different methods have been employed to determine directly or indirectly the IgG levels of sow colostrum. All of them have advantages and disadvantages. Brix refractometers have acceptable performance when compared to ELISA test, indicating that they can differentiate between good and poor-quality colostrum. However, digital refractometer presents the best correlation coefficient and should be the option for on-farm monitoring of colostrum. Additionally, the cell subsets observed in colostrum by flow cytometry correlated to immunoglobulins content, but further studies are required to understand their role and impact on piglet development.

\section{ACKNOWLEDGMENTS}

The authors thank summer program students, participating dairy farmers and veterinarians, as well as Cleiton Schuck, Joel Boff, Adilson Schell, Clair Klassmann, Ademir Muller, Hedo Haupt, José Bach, Lauri Lavrenz, Neori Gonçalves, Neudi Romani, Neudir Gastmann, Valdir Hegler, Valdori Petry for their technical assistance and data collection. This research was funded by Embrapa (13.16.05.031.00.00). The author(s) declared no potential conflicts of interest with respect to the research, authorship, and/or publication of this article.

\section{REFERENCES}

BALZANI, A.; CORDELL, H.J.; EDWARDS, S.A. Evaluation of an on-farm method to assess colostrum IgG content in sows. Animal, v.10, p.643-648, 2016.

BIELMANN, V.; GILLAN, J.; PERKINS N.R. et al. An evaluation of Brix refractometry instruments for measurement of colostrum quality in dairy cattle. J. Dairy Sci., v.93, p.3713-3721, 2010.

CABRERA, R.A.; LIN, X.; CAMPBELL, J.M.; MOESER, A.J.; ODLE, J. Influence of birth order, birth weight, colostrum and serum immunoglobulin $\mathrm{G}$ on neonatal piglet survival. $J$. Anim. Sci. Biotechnol., v.3, p.42, 2012. 
CARNEY-HINKLE, E.E.; TRAN, H.; BUNDY, J.W. et al. Effect of dam parity on litter performance, transfer of passive immunity, and progeny microbial ecology. J. Anim. Sci., v.91, p.2885-2893, 2013.

CASH, R.S.G. Colostral quality determined by refractometry. Equine Vet. Educ., v.11, p.36-38, 1999.

DEVILLERS, N.; FARMER, C.; LE DIVIDICH, J.; PRUNIER, A. Variability of colostrum yield and colostrum intake in pigs. Animal, v.1, p.10331041, 2007.

DEVILLERS, N.; LE DIVIDICH, J.; PRUNIER, A. Influence of colostrum intake on piglet survival and immunity. Animal, v.5, p.1605-1612, 2011.

DEVILLERS, N.; VAN MILGEN, .J; PRUNIER, A.; LE DIVIDICH, J. Estimation of colostrum intake in the neonatal pig. Anim. Sci., v.72, p.305313,2004

EDWARDS, S.A. Perinatal mortality in the pig: environmental or physiological solutions? Livest Prod Sci., v.78, p.3-12, 2002.

FERRARI, C.V.; SBARDELLA, P.E.; BERNARDI M.L. et al. Effect of birth weight and colostrum intake on mortality and performance of piglets after cross-fostering in sows of different parities. Prev. Vet. Med., v.114, p.259-266, 2014.

FLEENOR, W.A.; STOTT, G.H. Single radial immunodiffusion analysis for quantitation of colostral immunoglobulin concentration. J. Dairy Sci., v.64, p.740-747, 1981.

FOISNET, A.; FARMER, C.; DAVID, C.; QUESNEL, H. Relationships between colostrum production by primiparous sows and sow physiology around parturition. J. Anim. Sci., v.88, p.1672-1683, 2010.

HARKER, D.B. Simple Estimation of immunoglobulin content of ewe colostrum. Vet. Rec., v.103, p.8-9, 1978.

HASAN, S.; JUNNIKKALA, S.; VALROS, A.; PELTONIEMI, O.; OLIVIERO, C. Validation of Brix refractometer to estimate colostrum immunoglobulin $\mathrm{G}$ content and composition in the sow. Animal, v.10, p.1728-1733, 2016.

HURLEY, W.L.; THEIL, P.K. Perspectives on immunoglobulins in colostrum and milk. Nutrients, v.3, p.442-474, 2011.
KIELLAND, C.; ROOTWELT, V.; REKSEN, O.; FRAMSTAD, T. The association between immunoglobulin $\mathrm{G}$ in sow colostrum and piglet plasma. J. Anim. Sci., v.93, p.4453-4462, 2015.

KLOBASA, F.; BUTLER, J.E. Absolute and relative concentrations of immunoglobulins $\mathrm{G}, \mathrm{M}$, and $\mathrm{A}$, and albumin in the lacteal secretion of sows of different lactation numbers. Am. J. Vet. Res., v.48, p.176-182, 1987.

LE DIVIDICH, J.; ROOKE, J.A.; HERPIN, P. Nutritional and immunological importance of colostrum for the new-born pig. J. Agric. Sci., v.143, p.469-485, 2005.

LE JAN, C. A study by flow cytometry of lymphocytes in sow colostrum. Res. Vet. Sci., v.57, p.300-304, 1994.

MARKOWSKA-DANIEL, I.; POMORSKAMÓL, M.; PEJSAK, Z. Dynamic changes of immunoglobulin concentrations in pig colostrum and serum around parturition. Pol. J. Vet. Sci., v.13, p.21-27, 2010.

MELLOR, D.J.; COCKBURN, F.A. Comparison of energy metabolism in the new-born infant, piglet and lamb. Q. J. Exp. Physiol., v.71, p.361379, 1986.

OLIVIERO, C. Management to improve neonate piglet survival. In: RODRIQEZ-MARTINEZ, H.; SOEDE, N.; FLOWERS, W. (Eds.) Control of pig reproduction. 9.ed. Olsztyn, Poland: Contex, 2013. p.203-210.

QUESNEL, H. Colostrum production by sows: variability of colostrum yield and immunoglobulin G concentrations. Animal, v.5, p.1546-1553, 2011.

QUIGLEY, J.D.; LAGO, A.; CHAPMAN, C.; ERICKSON, P.; POLO, J. Evaluation of the Brix refractometer to estimate immunoglobulin $\mathrm{G}$ concentration in bovine colostrum. J. Dairy Sci., v.96, p.1148-1155, 2013.

ROOKE, J.A.; BLAND, I.M. The acquisition of passive immunity in the new-born piglet. Livest. Prod. Sci., v.78, p.13-23, 2002.

SCHNULLE, P.M.; HURLEY, W.L. Sequence and expression of the $\mathrm{FcRn}$ in the porcine mammary gland. Vet. Immunol. Immunopathol., v.91, p.227-2231, 2003. 
TUCHSCHERER, M.; PUPPE, B.; TUCHSCHERER, A.; TIEMANN U. Early identification of neonates at risk: Traits of newborn piglets with respect to survival. Theriogenology, v.54, p.371-388, 2000.

VALLET, J.L.; MILES, J.R.; REMPEL, L.A. A simple novel measure of passive transfer of maternal immunoglobulin is predictive of preweaning mortality in piglets. Vet. J., v.195, p.91-97, 2013.
XU, R.J.; WANG, F.; ZHANG, S.H. Postnatal adaptation of the gastrointestinal tract in neonatal pigs: a possible role of milk-borne growth factors. Livest. Prod. Sci., v.66, p.95-107, 2000.

ZOBEL, G.; RODRIGUEZ-SANCHEZ, R.; HEA, S.Y. WEATHERALL, A.; SARGENT, R. Validation of Brix refractometers and a hydrometer for measuring the quality of caprine colostrum. J. Dairy Sci., v.103, p.9277-9289, 2020 . 